\title{
Industrial democracy and corporate governance: two discourses of reform in liberal-market economies
}

\author{
Bernard Mees \\ Centre for People, Organisations and Work, \\ RMIT University, \\ GPO Box 2476, \\ Melbourne VIC 3001, Australia \\ Email: bernard.mees@rmit.edu.au
}

\begin{abstract}
Industrial democracy and corporate governance are intertwined discourses. In present-day use, however, the two expressions seem to represent as different perspectives as two related discursive traditions could become. At a time when calls have emerged for the intersection of the two narratives to be revisited, how the separation of these two related discourses occurred historically and what that separation has entailed seems of particular importance. The received corporate governance approach has become so dominant that it appears to have assumed the status of an ideology - an established way of thinking about the governance of corporations that is largely just assumed (rather than argued) in much financial and legal discourse. Seeking to understand why mainstream corporate governance scholarship has failed to engage with the historically key issue of industrial democratisation is the main purpose of this paper.
\end{abstract}

Keywords: agency theory; corporate governance; democratisation; employee participation; industrial democracy; pension funds; stakeholder theory.

Reference to this paper should be made as follows: Mees, B. (2017) 'Industrial democracy and corporate governance: two discourses of reform in liberalmarket economies', Int. J. Corporate Governance, Vol. 8, No. 1, pp.44-60.

Biographical note: Bernard Mees is a Senior Lecturer in Management and a former finance industry professional. His recent publications include Workers' Capital (with Cathy Brigden), the first academic survey of industry superannuation in Australia. His other publications include contributions to the Australian Journal of Corporate Law, the Journal of Management History, the Oxford Handbook of Management Theorists and the Routledge Companion to Business History.

\section{Introduction}

Industrial democracy and corporate governance are historically related notions, but that is not the impression one receives from introductory texts on corporate governance. From the other perspective, discussions of corporate governance often seem quite absent from journals such as Economic and Industrial Democracy or standard industrial relations textbooks. But in his 2013 contribution to the British Fabian Society's The Great Rebalancing, the 'Blue Labour' peer Maurice Glasman calls for an industrial democracy 
model to be adopted in British corporate governance, and recent developments in the pension (or superannuation) fund industry have similarly brought to the fore the issue of representation and 'independence' in commercial governance (Sayce et al., 2014). Glasman (2013) seeks to revisit and revive earlier debates regarding firm directorship and democratisation which have seemed largely forgotten in mainstream business governance discourse in the UK since the 1970s, as have similar advocates of employee representation on the boards of pension and superannuation funds (Markey et al., 2014).

In the 1960 s and 1970 s, the main controversies regarding the governance of firms concerned union and worker involvement in decision-making processes. Of the major industrialised economies, only commentators from the US stood significantly outside the key debates of the time. By the 1980s, however, a new concern had arisen in the US, one that was soon to spread throughout the industrialised world. This new concern was for the first time labelled 'corporate governance', but was articulated in a manner which displaced previously mainstream narratives that equally centred on debates regarding the proper governance arrangements to be adopted by listed firms. The label 'corporate governance' was the umbrella under which a particular kind of business reform was advanced, replacing one discursive formation with another in a classical Foucauldian manner (Mees, 2015).

This paper investigates how a socialist vision of democratised corporations was displaced by a liberal narrative derived from an implicit understanding that firms are characterised by a series of freely entered contracts. Where previous disputes regarding how firms should be governed focused on the lived experiences of employees within such enterprises (i.e. how their working lives are governed), a differently conceptualised approach that is primarily informed by liberal notions of contract displaced earlier understandings which invoked broader democratising aims and values. Rather than constituting an entrenched 'variety of capitalism' (Hall and Soskice, 2001), the liberal market approach to the governance of listed firms has seen a reconfiguration and obscuring of previous discourses of democratisation. Indeed, discourses of corporate governance have become so implicit and generally accepted in business thinking that corporate governance has itself arguably reached the level of an ideology, an ideology of financialisation (Ireland, 2009; Van der Zwan, 2014). A social democratic or partnership approach to the governance of listed firms has been abandoned in place of a politically and economically uneven narrative of social and economic contracts which neither reflects mainstream social sciences approaches to governance nor the broader historical development of the democratising ethic which had been such a mainstay of social sciences literature previously.

\section{Reforming narratives}

Considerations of the proper relationship between the employees, owners and directors of firms in a democratic society have a long history in Continental Europe where debates over worker representation and the effective functioning of governing boards were particularly common in the 1950s and 1960s (Neuloh, 1956; Meyers, 1958; Clegg, 1960; Czubek, 1968; Peterson, 1968; Blumberg, 1968; Emery and Thorsrud, 1969). Yet the notion of 'corporate governance' is commonly held to represent a quite different matter to that which led to the development of a requirement for employee-nominated directors on the boards of Scandinavian, German, Dutch and French firms (Haug, 2004a, 2004b; 
Müller-Jentsch, 2008; Conchon, 2013; Waddington and Conchon, 2016). Instead the intellectual tradition which has grown up about corporate governance since the 1960s has been limited by its development, particularly in terms of what Foucault (2003, pp.6-8) termed 'global theory'. Foucault argued that the key challenge for historians of ideas is to interrogate the reasons for the subjugation of earlier knowledges by global approaches and to rescue alternative intellectual traditions which may have been too readily passed over and forgotten. And in the case of corporate governance, the 'global theory' is the agency approach, first formulated by the American economists Jensen and Meckling (1976). In keeping with the earlier work of Mitnick (1975), the agency approach to corporate governance stresses the primacy of the rights of shareholders (as those who company management legally 'act for') in reflection of an intellectual status quo that had already been formulated in the US in the 1930s, particularly in terms of the outcome of a debate between Berle $(1931,1932)$ and Dodd $(1932,1935)$ in the Harvard Law Review, but was revisited by Berle (1959) perhaps most pointedly in his Power without Property: A new development in the American political economy.

As Foucault $(2008$, p.6) once famously put it, governance concerns the 'conduire la conduite' (regulation of behaviour) and is commonly held in the corporate context to be a different matter than management (Tricker, 2009). Corporations historically represent a legal structure, first developed to their present form in the nineteenth century, under which parliaments give certain legal protections to owners of corporations in order to encourage economic development. Before limited liability was introduced, for example, owners of firms could be imprisoned as debtors if the business failed (cf. the depiction of a debtors' prison in Dickens's Little Dorrit). The corporate form was created by parliaments for the sole purpose of aiding businesses to further develop the economic prospects of countries.

Corporate governance is concerned, therefore, with corporations and securities law, legal enforcement, standards of practice, duties, control and the effective operation of governing boards. As such, corporate governance cannot reasonably be restricted only to matters of firm performance, shareholder value and the functioning of directorial subcommittees, but needs to be taken more broadly as a concept. Corporate governance reflects both how parliaments enact legislation in order to govern broader social relationships, but also how firms themselves govern their employees and other resources - i.e. broader aspects of political economy. First coined as an expression by Eells (1960), corporate governance is both a firm-external and internal concern, a matter of both public and private government (Eells, 1962; Mees, 2015).

Industrial democracy, however, is a much older notion, but can also be understood as external or internal to a firm. First coined as an expression (démocratie industrielle) by Proudhon in the fifth edition of his Manual of the Stock Exchange Speculator (Proudhon 1857, p.461), industrial democracy contrasts with corporate governance genealogically as originally representing a radical discourse inherited from the nineteenth century worker movement. Proudhon was a proponent of cooperatives and mutualisation, and is best known as a founder of the anarchist movement that rejected the authoritarian socialism of Lenin and Marx (Prichard, 2013). Workers' councils had played a key role in the revolutionary movements in Germany, Italy and Russia, although in most cases they had been brought under union control by the 1920s (Eley, 2002, pp.160-164). Yet European industrial democracy also draws on Catholic social justice teaching as expressed in several papal writings, from the seminal encyclical Rerum novarum of Pope Leo XIII (1983) even to the writings of the conservative Pope St John Paul II who 
stressed in his Laborem exercens (John Paul 1981, III, 15) that "[t]he principle of the priority of labour over capital is a postulate of the order of social morality." The external notion of industrial democracy, as articulated by Webb and Webb (1897), concerns the rights of workers to join unions and to be represented by these external bodies in industrial bargaining, grievance handling and other kinds of employment matters. Internally, however, industrial democracy has usually been envisaged in the form of works councils, employee participation in decision-making, health and safety committees, and the election of worker directors to both pension-fund trustee boards and to the supervisory boards of publically listed business entities (Markey et al., 2010).

Jensen and Meckling's seminal statement of agency theory appeared during the time of the first major corporate governance debates in the US which arose after the spectacular failure of the Penn Central Transportation Company in 1970 (Daughen and Binzen, 1971; Sobel, 1977; Cheffins, 2013, 2015; Mees, 2015). Eells's work analysing the business corporation from a political-economy perspective seemed largely to have been forgotten by this time. But when his expression 'corporate governance' returned to the mainstream of business discourse, it did so in a much noisier manner than Eells had first proposed. The 1970s were the heyday of corporate activists such as Ralph Nader, and one of Nader's groups of consumer crusaders had even published a report into American corporate governance at the time that argued in favour of what would later become known as the stakeholder model of corporate governance (Graham, 2000; Marcello, 2004). The Nader report, Taming the Giant Corporation (Nader et al., 1976), was particularly focused on how senior management groups had in many instances become contemptuous of both consumers and shareholders. Nader and his supporters argued that US corporations needed to be regulated to force them to be more responsible not just to their shareholders, but also to societal concerns more generally.

By the 1970s, however, the even more fundamental reforms envisioned by advocates of industrial democracy on the European Continent had spread to the UK. Ever since Great Britain had entered the European Economic Community (EEC) in 1973, questions had been raised over the traditional structure of publically quoted British companies. After the war, the continental European model of two boards - one managing and one supervisory - had been further adapted in countries such as West Germany to accommodate the often-opposing interests of management and non-executive employees. Works councils of various forms had been current in German experience since the late nineteenth century as an 'experiment in industrial democracy' (Guillebaud, 1928) and these bodies had been strengthened after the war by the adoption of the first West German codetermination (Mitbestimmung) legislation (McGaughey, 2015). First developed in 1951 at a time when employers were still in a particularly weak political position (and, as McGaughey observes, not forced upon the country by the Allies as has often been claimed), in 1976 the German parliament had even extended the number of employee-elected positions on German supervisory boards to $50 \%$ in large enterprises (i.e. those with over 2,000 employees). German-style codetermination was duly presented as an alternative business structure, tried and tested in the EEC's dominant economy, and constituted a quite different model for the modern British public company (Mertens and Schanze, 1979; Havlovic, 1990; Fetzer, 2010).

In 1975, the Labour government of Harold Wilson consequently appointed a commission of inquiry to respond to the matters raised in the European Commission's Draft Fifth Company Law Directive, the first version of which (published in 1972) proposed the institution of a modified West German system of corporate governance right 
across the EEC. The Draft Fifth Directive was intended as an EEC-wide company-law harmonisation measure that would protect West German businesses from 'social dumping' - i.e. it would stop multinationals from employing their staff in member countries that had the worst employment protections (Commission of the European Communities, 1972; Dalton, 1974; Conlon, 1975; Schmitthoff, 1976; Bullock, 1977; Davies and Lord Wedderburn of Charlton, 1977; Creighton, 1977; Gold, 2010). The Conservative Party had duly proposed amending British company law to include a statutory duty for directors to take into account the interests of both shareholders and employees (Department of Trade and Industry, 1973). But when the Labour government responded with a White Paper on industrial democracy in 1978, British business groups were appalled. The committee of inquiry led by the historian (and Labour peer) Allan Bullock concentrated on how electing union representatives to company boards might lead to less industrial conflict in light of the undeniable economic success of West German firms under codetermination. Nonetheless as the government of James Callaghan (Wilson's Labour Party successor) moved into crisis during the strike-riddled 'Winter of Discontent' of 1978-1979, the UK's industrial democracy model for the public company soon disappeared from the mainstream policy agenda (Lopez, 2014; Williamson, 2016).

The majority report of the Bullock committee had proposed the adoption of a single board in British public companies of over 2000 employees with worker-elected directors making up as many members of the board as shareholder-elected directors, with the remainder being independent of both unions and shareholders (the $2 x+y$ model). As the committee noted (Bullock, 1977, p.41):

\begin{abstract}
it seems to us (as it did to most witnesses) that to regard the company as solely the property of shareholders is to be out of touch with the reality of the present day company as a complex social and economic entity, subject to a variety of internal and external pressures, in which the powers of control have passed from the legal owners to professional management.
\end{abstract}

The minority report, prepared by the industrialists on the committee (who were constrained by the committee's terms of reference to advise on how, not whether codetermination should be implemented), instead recommended a dual-board model more along the lines which obtained in West Germany.

The Bullock report proved an immediate failure, however. Upon its publication in January 1977, the industrial democracy proposals were loudly criticised by the Confederation of British industry (CBI) The CBI opposed the matter of union-appointed directors outright. The Callaghan government in turn quickly retreated, its White Paper published in May 1978 refusing to "impose a standard pattern of participation on industry by law" (Department of Employment 1978, p.2), calling instead for the extension of participation through industrial agreements (Wedderburn of Charlton, Lord, 1984; Carter, 1989; Williamson, 2016). Indeed, with the 1979 replacement of Callaghan as British Prime Minster by the Conservative Party's Margaret Thatcher, experiments with worker directors in nationalised industries were ended and the EEC proposals for codetermination were comprehensively rebuffed. Despite British companies such as ICI still experimenting with works councils in the late 1970s, the idea of industrial democracy quickly disappeared from the British public agenda.

Instead, a new discourse arose in the 1980s. Reversing the direction of influence which had traditionally applied in such matters, the British approach to public company governance reform would become increasingly American in style and focus during the 
Prime Ministership of Thatcher and her Conservative successor John Major, with British public companies appointing an increasing number of non-executive or independent directors, establishing audit and nominating committees, and pursuing other comparable ways of improving firm performance through formal mechanisms of governance (Mees, 2015). Any suggestions of industrial democracy were now seen as too radical (much as the terms of reference of the Bullock committee had described the proposed adoption of codetermination). Clearly understood as an Americanism, 'corporate governance' was imported into the UK during the 1980s at the discursive expense of codetermination. Instead of in terms of democratisation, the boards of British public companies were reformed in a manner which sought to increase economic efficiency and to better represent the interests solely of shareholders.

\section{Employee participation and representation}

The British situation previously had been mixed. The Webbs had opposed worker involvement in management originally because of the low reputation that British employee shareholding schemes had achieved in the late nineteenth century, but by 1920 had come around to an acceptance of union involvement in the management of industry (Webb and Webb, 1920; McGaughey, 2014). Whitley Works Committees had also been formed in many industries between the two World Wars in a Taylorist attempt to 'tap labour's brains' (Cooke and Murray, 1940), but most of the UK's Joint Industrial Councils had been abolished by the 1970s (Stitt, 2006; Patmore, 2016). British trade unions did not actively seek to become involved in German-style codetermination arrangements until the 1960s (McGaughey, 2014; Williamson, 2016).

In the US, works councils and employee involvement in industrial decision-making had first been advocated during the First World War, but had subsequently been advanced more successfully by advocates of Taylorism as a method for improving production processes. Joint labour-management arrangements were advocated most notably by Morris Cooke, Frederick Taylor's ghost writer (i.e. the actual author of The Principles of Scientific Management), as the Taylor movement (particularly after Taylor's death) attempted to extend Taylor's 'mental revolution' by engaging union support (Cooke and Murray, 1940; Derber, 1970; Wrege and Stotka, 1978; Lichtenstein and Harris, 1993; McCartin, 1998; Summers, 2000; Bruce and Nyland, 2011; Nyland et al., 2014). Works councils were judged especially effective when considering technical aspects of production and were a key development in the emergence of codetermination in Europe. Even the dream of a more rational fixing of rates of remuneration (partly as a reflection of the Socialist Calculation debates being held in Europe at the same time) was reflected in the late Taylorist experimentation with works councils (Auerbach and Sotiropoulos, 2014). Works councils in Europe have since tended to be mostly involved in employee-centred concerns such as occupational health and safety, employee discipline and redundancy entitlements. More traditional industrial matters could be resolved by joint union-management consultative committees or other similar bodies.

In the UK, a successful system of mandatory worker-employer participation had nonetheless been instituted in the health and safety area on the recommendations of the Robens Report (1972), and similar arrangements had long obtained on the boards of pension funds, particularly in the US where the Taft-Hartley Act of 1947 had limited union participation on the boards of retirement-savings plans to 50\% (McCarthy, 2014). 
The UK's industrial democracy proposals of the late 1970s, however, also reflected a uniquely British concern in which industrial relations was largely unregulated, an environment that had led to an ungoverned industrial system where wild-cat strikes and disputes even within unions were very much the order of the day (Fox, 1985). Rather than adopting German-style codetermination, the response under Thatcher was to regulate union activity and industrial relations more generally (Marsh, 1991; Shackleton, 1998). But in the 1970s, industrial democracy seemed to have a particular salience throughout much of the Western world and had led to the expectation among many of its proponents that its adoption was inevitable.

Yet the development of a new discourse of corporate reform in the US in the 1970s rapidly led to the dominance of a renewed shareholder-primacy approach to corporate governance. As Milton Friedman had argued since the 1960s (Friedman, 1962), corporations existed to make money, and the main claimants on that profit had been intended to be shareholders historically, not management elites or workers. The new American economic approach to corporate governance that first arose in the 1970s quickly became principally focused on maximising returns to shareholders, not issues of democratisation (Mees, 2015). Works councils and worker directors seemed quite outside the bounds of the new discourse of American corporate governance reform.

Much of the discussion of industrial democracy in the Anglo-Saxon countries has subsequently seen the scope of the democratising narrative retreat to that of the external model promoted in the late nineteenth century by the Webbs or to an even more etiolated management-controlled model of 'participation' or 'voice' (Bixler, 1985; Mitchell, 1998; Budd, 2004; Wilkinson et al., 2010). Industrial democracy in this understanding is to be restricted to the right of workers' voices to be heard through their unions - bodies external to the firm - or are reduced to a purely consultative (and often only token) role. Under codetermination, it is the firm itself which is democratised as shareholder rights to be represented on the board of governance are balanced with those of the right of employees to be heard. The American discourse of corporate governance, however, does not consider democratisation at all, with emphasising the rights of shareholders (over management) often serving as a proxy for democratisation more generally.

Most of the focus of liberal reform in the US has been argued in terms of contractual shareholder rights. Figures such as Robert Monks (Rosenberg, 1998) have campaigned unabashedly for the property rights of shareholders to be upheld, not for those of employees or society more generally. Nader's approach was to focus more on consumers, extending the democratic franchise from shareholders to shareholders and consumers. While Monks sought to democratise corporations from the perspective of their nominal owners, Nader and his followers sought democratisation principally from the perspective of their customers.

By the 1980s, Nader (1984) had despaired of achieving real reform from the perspective of corporate governance. Yet his focus on stakeholders lived on. When stakeholder theory had first been formally propounded by Dill (1975), however, it was seen principally from the perspective of firm strategy - how could a business best manage its relationships with each of its key constituencies? In the 1980s, business ethicist Ed Freeman (1984) further developed the stakeholder approach along Rawlsian lines (Rawls, 1971), underscoring the liberal understanding of the firm as a series of contracts. Further 'constitutionalising' (Miller, 1959) of the American corporation occurred with the introduction of conservation laws, prohibitions on discrimination in hiring and the further strengthening of the legal rights of shareholders, employees and consumers. In 1986, for 
example, the US Supreme Court confirmed the right of women employees to sue for sexual harassment and in 1992 federal proxy rules for shareholders were amended in a manner that allowed investors to increase their ability to communicate with each other (Anderson, 1987; Schwab and Thomas, 1998). But such an approach to democratising US business remains an external (or restricted/token) one, not internal (and actual) as in the European codetermination model.

This externalising has since become the norm in all of the Anglo-Saxon countries. In the externalised model of industrial democracy, employee voices within the firm are managed by unions and senior management. Rather than a fully democratised model, a paternalistic approach instead often ensues. With declining union membership, employee voice retreats to a form of managed employee participation which is at best semidemocratic. Instead of corporate democracies, listed firms remain largely undemocratised under contemporary conceptualisations of corporate governance and industrial democracy. The external model seems to conflict with the broader social-democratic standards which are customarily advanced in most other areas of the political economy today.

The contractual American agency model of the firm also seems discontinuous with the development of management thought more generally. The main problem with the external model from a management history perspective is not merely the defeat of late Taylorism (with the advocacy of employee involvement in decision-making by Taylor's successors such as Cooke) that this development reflects, but that it encourages the form of managerialist paternalism that resurfaced so obviously in the organisational development movement of the 1980s. Where concerns about employee anomie and the negative influence that organisational structures can have on personal development were once at the fore in organisational studies (Mayo, 1949; Argyris, 1957; Blauner, 1964; Maslow, 1965), the focus on improving firm performance which was characteristic of the neo-human relations movement is often manipulative and coercive in nature, its associated discipline of leadership studies often simply totalitarian (i.e. one of 'total claim') (Bracher, 1984, p.47; Hawkins, 1997; Pinha e Cuna et al., 2010; Godard, 2014). Very little acknowledgement of the notions of democratisation which underpinned older understandings of industrial democracy is represented in this literature.

Nonetheless in Continental Europe, works councils were the subject of new regulation in 1994 (renewed in 2009) as employee participation has become a mandatory aspect of the EU's social democracy agenda (Council of the European Union, 1994; Gold, 2010; Lecher et al., 2002; Whittall et al., 2007). The EEC's Draft Fifth Directive was finally abandoned in 2004, but two years later a review of codetermination in Germany resulted in conservative Chancellor Angela Merkel publicly supporting its role in the 'social market economy' (Biedenkopf, 2006; Silvia, 2013, p.60). Renewed British debates concerning the wisdom of the American approach to corporate governance are represented in Lord Glasman's appeal to revisit industrial democracy and recent Trades Union Congress studies in the UK (Williamson et al., 2014). In fact in July 2016 the soon-to-be British Prime Minister Theresa May even promised "we're going to have not just consumers represented on company boards, but employees as well" (if only to recant several months later) (May 2016). The financial crisis of 2008 has led to new criticism of the neoliberal model of corporate governance triumphantly claimed to represent an 'end of history' by two Harvard business professors in 2001 shortly before the collapse of Enron (Hansmann and Kraakmann, 2001). But no mention of such matters appears in Durisin and Puzone's 2009 survey of the 'maturation of corporate governance research' 
or even Thomas Donaldson's (2012) more recent epistemic critique of agency theory, much as if industrial democracy has been totally eclipsed from the canonical narratives of contemporary corporate governance.

The decline of industrial democracy in the US in the 1940s and 1950s led to the removal of the theme from the business school literature. A continued matter of interest in Europe and the UK throughout the 1960s and 1970s, the only American academic contributions to the democratising debate during this period seem to have been dismissals of industrial democracy on (unclear) economic grounds (Sturmthal, 1964; Jensen and Meckling, 1979; Jacoby, 1985a, 1985b; Dickman, 1987; Frege, 2006). An American League for Industrial Democracy has existed since 1905, but even Nader, whose advocates styled his reform proposals 'corporate democracy', criticised industrialdemocracy initiatives as unworkable in the US (Nader et al., 1976; Johnpoll and Yerburgh, 1980). Subsumed in much subsequent literature under the less charged description of 'employee participation', industrial democratisation has been displaced from the canonical narratives of business reform by shareholder-primacy models of corporate governance. As Raymond Williams (1961) stressed, however, democratisation was one of the key social and cultural developments of the twentieth century, and remains an outstanding matter of tension in the contemporary political economy.

\section{Pension fund governance}

It is this displacement of notions of industrial democracy at the expense of corporate governance discourse which most characterises contemporary discussions of the role of 'independent' trustees on pension and superannuation fund boards (Gold, 2008). Pension funds (or superannuation funds as they were formerly known in the UK) have traditionally been governed on industrial democracy grounds, with seats shared among employer and employee trustees, in a manner often described as 'representative' rather than 'democratic' - in fact with the number of employee representatives often regulated (Sayce and Gold, 2011). Many occupational pension plans were won as the result of industrial campaigns and their trustees are consequently described in union literature as stewards of 'workers' capital' (Westar and Verma, 2007; Habbard, 2011). And as the representatives of workers, unions have long had an especial interest in the safekeeping of employees' retirement-savings funds. Yet the industrial democracy model of pension and superannuation fund governance is currently under assault, as advocates of corporate governance thinking aim to extend the listed corporation model into the retirementsavings arena.

Applying the corporate governance principle of independence to pension fund boards has been a growing feature of American public pension schemes where inside directors (representing government employers) have often failed the beneficiaries of the plans (Hess and Impavido, 2004; Ambachtsheer, 2007). Requirements to include independent trustees were also introduced in the UK under the Occupational Pension Schemes (Charges and Governance) Regulations 2015, but not in a manner that (as yet) disturbs pre-existing industrial democracy arrangements. Instead, the anti-democratic nature of the calls for fund trustee 'independence' are best demonstrated in Australia where in 2015 the conservative government introduced legislation to mandate a minimum of onethird independent trustees on superannuation fund boards with a recommendation that funds move to a $50 \%$ quota, much as applies for Australian listed companies 
(Frydenberg, 2015). The legislation was eventually defeated, but contrary evidence produced by advocates of the industrial democracy model employed in union-sponsored retirement-savings plans was summarily dismissed by the government at the time (Markey et al., 2014).

A similar debate is presently occurring in the UK. Mandatory employee involvement was introduced under the UK Pensions Act 2004 on the basis that it would improve fund accountability, but groups such as BESTrustees and Law Debenture have continued to advocate for more independent trustees to be appointed to pension fund boards (Maton, 2010; Farand, 2014). Independent trustees are being promoted both by academic and professional opinion as a way of improving the performance of British pension funds in terms of improving 'board capital' (Hillman and Dalziel, 2003) at the expense of employer and employee representatives. The notion that retirement savings funds are a key form of 'union business' is typically passed over in these debates, as is the lack of employee involvement in traditional corporate governance thinking. Employee representatives are widely held to have the equivalent 'outsider' function as independent directors do in the mainstream pension funds governance literature (Hess, 2005), but this matter has also been passed over by the advocates of independent trustees. More independents necessarily means a better functioning board according to the proponents of this corporate governance model, even if the agency problems of a retirement-savings fund are obviously quite different from those which apply in a listed corporate entity (Sayce et al., 2014). The notion of independence derived from corporate governance discourse has clearly spread into the retirement-savings area in an ideological rather than a democratic or evidence-based manner.

\section{Organisational studies}

A key theme in the business ethics literature is how a democratic organisational culture may encourage employees to take responsibility for their actions, whereas a more authoritarian one may not (Trevino, 1986). As Denhart (1981, p.32) expresses it "we originally sought to construct social institutions that would reflect our values and beliefs; now there is the danger that our values would reflect our institutions". But the plethora of ethics codes and value statements promoted in contemporary business practice often seem more to represent instruments of social control, rather than expressions of democratisation. Similarly, although the stakeholder approach was first proposed in reaction to the influence of Nader's attacks on US corporations (Dill, 1975), Donaldson (2012) observes that interests other than those of managers and shareholders are often dismissed in the mainstream of corporate governance literature. Arguments over who the 'residual claimants' on the profits of the firm should be often boil down to disagreements along the grounds of what Donaldson $(2012$, p.269) characterises as an ideological preference of the "I like oysters and think everyone should eat oysters" versus "I like strawberries and think everyone should eat strawberries" variety. Jensen (2002), for example dismisses stakeholder theory as politicising and irrational, while Freeman et al. (2004, p.364) defend their approach by criticising 'shareholder ideologists' who 'serve neither truth nor freedom'. The demarcation between stakeholder theorists and the mainstream of corporate governance research may again here be characterised as a reflection of an implicit debate over democratisation. 
Similar criticisms can also be raised of other liberal approaches to democratisation the 2012 call to make Britain a 'John Lewis economy' by former Deputy Prime Minister (and Liberal Democrat leader) Nick Clegg was made without cognizance of the degeneration of democratic structures which have been a recent characteristic of the John Lewis Partnership, one of the largest employee-owned firms in Europe (Cathcart, 2014; Paranque and Willmott, 2014). As Hartmann (2014) claims, it is in studies of 'alternative organisations' (in the sense of alternatively governed ones) where empirical and ideological claims concerning the democratisation of firm governance can most profitably be examined, modelled and explained. The lack of comprehensive studies of the effects of labour trustees on pension fund performance directly reflects the lack of interest shown by corporate governance researchers on the influence of employee directors, mutualism (and demutualisation), employee ownership, cooperative ownership, and other forms of formal business democratisation generally in the field. The eclipse of the discourse of democratisation in the 1980s has been a key influence in many fields of organisational study, not merely that of the mainstream of explicitly corporate governance-focused discourse itself.

\section{Conclusion}

Hayek (1944, p.98) claimed in his Road to Serfdom that "what matters is that we have some choice", that "there is almost always a way for the able" to leave a job that "becomes quite intolerable." And similarly, in his recent book Democracy: Where and Where Not Gray (2011) considers the relationship of US business to American democracy purely in terms of whether corporations should be able to influence the political process - there seems to be a general lack of understanding in such works that democracy is not something necessarily external to the firm, but that it is something that can take place within it. As Ellerman (1990, p.32) has stressed, "[d]iscussions of corporate governance are often clouded by insufficient attention to the distinction between those who are governed by the corporation and those whose interests are only affected by the firm." The fundamental question of political economy - how should we be governed? - seems to be absent from most debates in corporate governance. It is as if the concept of democracy has somehow become alien to the narrative tradition which obtains in corporate governance circles in the main liberal-market economies currently.

Corporate governance is duly seen today by its critics largely as an impossibly conservative, neo-liberal project - indeed much as if it were an inversion of the older movement towards industrial democracy. As Donaldson (2012) adumbrates, the agency approach to corporate governance has tended to crowd out other normative concerns in the associated intellectual discourse. Beginning as a call for business governance reform, for democratising American corporations, since the 1980s narratives of corporate governance, particularly in their agency-theory form, have been conceptualised predominately as management and shareholder-focused. Originally advanced in terms of democratisation, corporate governance is now articulated predominately in a manner significantly at odds with earlier ideals of industrial democratisation. Yet the main criticisms of contemporary corporate governance theory and practice tend to be liberal and contractual in their nature, stressing how businesses should be more responsible to the societies that give them legal licence, for them to treat all their stakeholders reasonably and nicely. Democratisation in this model makes appeal only to the broader 
social licence enjoyed by listed entities, not to their formal democratisation. Debates about stakeholder representation and corporate social responsibility have often acted to obscure rather than focus on the key issue that was encapsulated in earlier debates over industrial democratisation. Indeed the democratising of the governance of business entities is not even considered in much contemporary corporate governance discourse, solutions to wider issues of social concern typically being proposed either through the means of developing more focus on personal ethics, corporate public engagement or a clearer regulation of the nature of the duties of managers and directors towards business stakeholders in a liberal-contractual view of the nature of the firm.

\section{References}

Ambachtsheer, K. (2007) Pension Revolution: A Solution to the Pensions Crisis, Wiley, Hoboken, NJ.

Anderson, K.S. (1987) 'Employer liability under title VII for sexual harassment after Meritor Savings Bank v. Vinson', Columbia Law Review, Vol. 87, No. 6, pp.1258-1279.

Argyris, C. (1957) Personality and Organization: The Conflict between System and the Individual, Harper, New York.

Auerbach, P., and Sotiropoulos, D.P. (2014) 'Revisiting the socialist calculation debate: the role of markets and finance in Hayek's response to Lange's challenge', in Bellofiore, R., Karwowski, E. and Toporowski, J (Eds.): Economic Crisis and Political Economy: Volume 2 of Essays in Honour of Tadeusz Kowalik, Palgrave Macmillan, Basingstoke, pp.212-230.

Berle Jr., A.A. (1931) 'Corporate powers as powers in trust', Harvard Law Review, Vol. 44, pp.1049-1074.

Berle Jr., A.A. (1932) 'For whom are corporate managers trustees: a note', Harvard Law Review, Vol. 45, pp.1365-1372.

Berle Jr., A.A. (1959) Power without Property: A New Development in the American Political Economy, Harcourt, Brace, New York.

Biedenkopf, K. (2006) Bericht der wissenschaftlicher Mitglieder der Kommission zur Modernisierung der deutschen Unternehmensmitbestimmung, Die Kommission, Berlin.

Bixler, A. (1985) 'Industrial democracy and the managerial employee exception to the national labor relations act', University of Pennsylvania Law Review, Vol. 133, pp.441-468.

Blauner, R. (1964) Alienation and Freedom: The Factory Worker and his Industry, Chicago University Press, Chicago.

Blumberg, P. (1968) Industrial Democracy: The Sociology of Participation, Constenoble, London.

Bracher, K.D. (1984) The Age of Ideologies: A History of Political Thought in the Twentieth Century, translated by Osers, E., Weidenfeld \& Nicolson, London.

Bruce, K. and Nyland, C. (2011) 'Elton Mayo and the deification of human relations', Organization Studies, Vol. 32, pp.383-405.

Budd, J.W. (2004) Employment with a Human Face: Balancing Efficiency, Equity and Voice, Cornell University Press, Ithaca, NJ.

Bullock, A. (1977) Report of the Committee of Inquiry on Industrial Democracy, HMSO, London.

Carter, A. (1989) 'Industrial democracy and the capitalist state', in Duncan, G. (Ed.): Democracy and the Capitalist State, Cambridge University Press, Cambridge, pp.277-294.

Cathcart, A. (2014) 'Directing democracy: competing interests and contested terrain in the John Lewis partnership', Journal of Industrial Relations, Vol. 55, No. 4, pp.6011-6020.

Cheffins, B.R. (2013) 'The history of corporate governance', in Wright, M., Siegel, D.S., Keasey, K. and Filatotchev, I. (Eds.): The Oxford Handbook of Corporate Governance, Oxford University Press, Oxford, pp.46-64.

Cheffins, B.R. (2015) 'Corporate governance since the managerial capitalism era', Business History Review, Vol. 89, No. 4, pp.717-744. 
Clegg, H.A. (1960) A New Approach to Industrial Democracy, Blackwell, Oxford.

Commission of the European Communities. (1972) 'Proposal for a fifth directive on the structure of sociétés anonymes', Bulletin of the European Communities Supplement 10/72, Office for the Official Publications of the European Communities, Luxembourg.

Conchon, A. (2013) Workers' Voice in Corporate Governance: A European Perspective, TUC, London.

Conlon, T. (1975) 'Industrial democracy and EEC company law: a review of the draft fifth directive', International and Comparative Law Quarterly, Vol. 24, No. 2, pp.348-359.

Cooke, M.L. and Murray, P. (1940) Organized Labour and Production: Next Steps in Industrial Democracy, Harper \& Bros, New York.

Council of the European Union. (1994) Council Directive 94/45/EC of 22 September 1994 on the Establishment of a European Works Council or a Procedure in Community-scale Undertakings and Community-scale Groups of Undertakings for the Purposes of Informing and Consulting Employees.

Creighton, W.B. (1977) 'The Bullock report: the coming of the age of democracy', British Journal of Law and Society, Vol. 4, pp.1-17.

Czubek, G. (1968) Die Unternehmensverfassung: Wirtschaftliche Grundlagen, juristische Reformbestrebungen und rechtsdogmatische Widerstände, Dissertation, University of Freiburg.

Dalton, C. (1974) 'Proposals for the unification of corporation law within the European economic community: effect on the British company', New York University Journal of International Law and Politics, Vol. 7, pp.59-102.

Daughen, J.R. and Binzen, P. (1971) The Wreck of the Penn Central, Little, Brown, Boston.

Davies, P. and Lord Wedderburn of Charlton. (1977) 'The land of industrial democracy', Industrial Law Journal, Vol. 6, pp.197-211.

Denhart, R.B. (1981) In the Shadow of the Organisation, Regents Press, Lawrence, KS.

Department of Employment (UK). (1978) Industrial Democracy, HMSO, London.

Department of Trade and Industry (UK). (1973) Company Law Reform, HMSO, London.

Derber, M. (1970) The American Idea of Industrial Democracy, 1865-1965, University of Illinois Press, Urbana, IL.

Dickman, H. (1987) Industrial Democracy in America: Ideological Origins of National Labor Relations Policy, Open Court, La Salle, IL.

Dill, W.R. (1975) 'Public participation in corporate planning-strategic management in a Kibitzer's world', Long Range Planning, Vol. 8, No. 1, pp.57-63.

Dodd Jr., E.M. (1932) 'For whom are corporate managers trustees?' Harvard Law Review, Vol. 45, pp.1145-1163.

Dodd Jr., E.M. (1935) 'Is effective enforcement of the fiduciary duties of corporate managers practicable?' University of Chicago Law Review, Vol. 2, pp.194-207.

Donaldson, T. (2012) 'The epistemic fault line in corporate governance', Academy of Management Review, Vol. 37, No. 2, pp.256-271.

Durisin, B. and Puzone, F. (2009) 'Maturation of corporate governance research 1993-2007: an assessment', Corporate Governance: An International Review, Vol. 14, No. 3, pp.266-291.

Eells, R. (1960) The Meaning of Modern Business: An Introduction to the Philosophy of Large Corporate Enterprise, Colombia University Press, New York.

Eells, R. (1962) The Government of Corporations, Free Press of Glencoe, New York.

Eley, G. (2002) Forging Democracy: The History of the Left in Europe, 1850-2000, Oxford University Press, Oxford.

Ellerman, D.P. (1990) The Democratic Worker-owned Firm: A New Model for the East and West, Unwin Hyman, London. 
Emery, F. and Thorsrud, E. (1969) Form and Content in Industrial Democracy: Some Experiences from Norway and Other European Countries, Tavistock, London.

Farand, L. (2014) The trustee factor, Engaged Investor (3 Feb).

Fetzer, T. (2010) 'Defending Mitbestimmung: German trade unions and European company law regulation (1967-2000)', Economic and Industrial Democracy (suppl), Vol. 31, No. 4, pp.24-39.

Foucault, M. (2003) "Society Must Be Defended": Lecture at the Collège de France, 1975-1976, translated by Macey, D., Picador, New York.

Foucault, M. (2008) Le gouvernement de soi et des autres: Cours au Collège de France (1982-1983), Paris, Seuil.

Fox, A. (1985) History and Heritage: The Social Origins of the British Industrial Relations System, Allen \& Unwin, London.

Freeman, R.E. (1984) Strategic Management: A Stakeholder Approach, Pitman, Boston.

Freeman, R.E., Wicks, A.C. and Parmar, B. (2004) 'Stakeholder theory and "the corporate objective revisited", Organization Science, Vol. 15, No. 3, pp.364-369.

Frege, C. (2006) 'The discourse of industrial democracy: Germany and the US revisited', Economic and Industrial Democracy, Vol. 26, No. 1, pp.151-175.

Friedman, M. (1962) Capitalism and Freedom, University of Chicago Press, Chicago.

Frydenberg, J. (2015) Improving Superannuation Governance. Available at: http://jaf.ministers. treasury.gov.au/media-release/034-2015/ (26 June 2015).

Glasman, M. (2013) 'Corporate governance reform', in Harrop, A. (Ed.): The Great Rebalancing: How to Fix the Broken Economy, Fabian Society, London, pp.11-18.

Godard, J. (2014) 'The psychologisation of employment relations?' Human Resource Management Journal, Vol. 24, No. 1, pp.1-18.

Gold, M. (2008) “"A silent revolution”? The role of union trustees in occupational pension funds in the UK: Lessons from the 1970s and 1980s', Historical Studies in Industrial Relations, Vols. 25/26, pp.141-176.

Gold, M. (2010) 'Employee participation in the EU: The long and winding road to legislation', Economic and Industrial Democracy, Vol. 31, pp.9-23.

Graham, K. (2000) Ralph Nader: Battling for Democracy, Windham, Denver.

Gray, C.B. (2011) Democracy: Where and Where Not, RoseDog, Pittsburg.

Guillebaud, C.W. (1928) The Works Council: A German Experiment in Industrial Democracy, Cambridge University Press, Cambridge.

Habbard, P. (2011) 'The stewardship of European workers' capital in times of crisis', Transfer, Vol. 17, No. 1, pp.59-73.

Hall, P.A. and Soskice, D. (Eds.) (2001) Varieties of Capitalism: The Institutional Foundations of Comparative Advantage, Oxford University Press, Oxford.

Hansmann, H. and Kraakmann, R. (2001) 'The end of history for corporate law', Georgetown Law Journal, Vol. 89, pp.439-468.

Hartmann, R.K. (2014) 'Subversive functionalism: for a less canonical critique in critical management studies', Human Relations, Vol. 67, No. 5, pp.611-632.

Haug, R. (2004a) 'The history of industrial democracy in Sweden: Industrial revolution to 1980', International Journal of Management, Vol. 21, No. 1, pp.7-15.

Haug, R. (2004b) 'Industrial revolution to 1980: The history of industrial democracy in Denmark and Norway', International Journal of Management, Vol. 21, No. 2, pp.135-143.

Havlovic, S.J. (1990) 'German works councils: a highly evolved institution of industrial democracy', Labour Studies Journal, Vol. 15, No. 2, pp.62-71.

Hawkins, P. (1997) 'Organizational culture: Sailing between evangelism and complexity', Human Relations, Vol. 50, No. 4, pp.417-440. 
Hayek, F. (1944) The Road to Serfdom, Routledge, London.

Hess, D. (2005) 'Protecting and politicizing public pension fund assets: empirical evidence on the effects of governance structures and practices', UC Davis Law Review, Vol. 39, pp.187-224.

Hess, D. and Impavido, G. (2004) 'Governance of public pension funds: Lessons from corporate governance and international evidence', in Muslem, A.R. and Palacios, R. (Eds.): Public Pension Fund Management, The World Bank, Washington, DC, pp.49-89.

Hillman, A.J. and Dalziel, T. (2003) 'Boards of directors and firm performance: integrating agency and resource dependence perspectives', Academy of Management Review, Vol. 28, pp.383-396.

Ireland, P. (2009) 'Financialization and corporate governance', Northern Ireland Legal Quarterly, Vol. 60, No. 1, pp.1-34.

Jacoby, S.M. (1985a) 'Union-management cooperation in the United States: Lessons from the 1920s', Industrial and Labor Relations Review, Vol. 37, pp.18-33.

Jacoby, S.M. (1985b) 'Union-management cooperation in the United States during the Second World War', in Dubofsky, M. (Ed.): Technological Change and Workers' Movements, Sage, Beverley Hills, pp.100-129.

Jensen, M.C. (2002) 'Value maximization, stakeholder theory, and the corporate objective function', Business Ethics Quarterly, Vol. 12, No. 2, pp.235-256.

Jensen, M.C. and Meckling, W.H. (1976) 'Theory of the firm: managerial behavior, agency costs, and ownership structure', Journal of Financial Economics, Vol. 3, No. 4, pp.305-360.

Jensen, M.C. and Meckling, W.H. (1979) 'Rights and production functions: an application to labormanaged firms and codetermination', Journal of Business, Vol. 52, No. 4, pp.469-506.

Johnpoll, B.K. and Yerburgh, M.R. (Eds.) (1980) The League for Industrial Democracy: A Documentary History, Vol. 3, Greenwood, Connecticut.

John Paul II (1981) Encyclical Laborem Exercens: Addressed by the Supreme Pontiff John Paul II to his Venerable Brothers in the Episcopate to the Priests, to the Religious Families, to the Sons and Daughters of the Church and to All Men and Women of Good Will on Human Work on the Ninetieth Anniversary of Rerum Novarum, St Paul Publications, Homebush, NSW.

Lecher, W., Platzer, H-W., Rub, S. and Weiner, K-P. (2002) European Works Councils: Negotiated Europeanisation; between Statutory Framework and Social Dynamics, Ashgate, Aldershot.

Leo, XIII. (1983) Rerum Novarum: Encyclical Letter of Pope Leo XIII on the Condition of the Working Classes, translated by Kirwan, J., Catholic Truth Society, London.

Lichtenstein, N. and Harris, H.J. (Eds.) (1993) Industrial Democracy in America: The Ambiguous Promise, Cambridge University Press, Cambridge.

Lopez, T.M. (2014) The Winter of Discontent: Myth, Memory and History, Liverpool University Press, Liverpool.

Marcello, P.C. (2004) Ralph Nader: A Biography, Greenwood, Westport, CT.

Markey, R., Patmore, G. and Balnave, N. (2010) 'Worker directors and worker ownership/cooperatives', in Wilkinson, A.J., Gollan, P.J., Marchington, M. and Lewin, D. (Eds.): The Oxford Handbook of Participation in Organisations, Oxford University Press, Oxford, pp.237-257.

Markey, R., Rafferty, M., Thornwaite, L., Wright, S. and Angus, C. (2014) The Success of Representative Governance on Superannuation Boards, Centre for Workplace Futures, Macquarie University, Sydney.

Marsh, D. (1991) 'British industrial relations policy transformed: the Thatcher legacy', Journal of Public Policy, Vol. 11, No. 3, pp.291-313.

Maslow, A. (1965) Eupsychian Management: A Journal, Irwin, Homewood, IL.

Maton, B. (2010) 'The paradox of professional trustees', Financial Times (21 Mar).

May, T. (2016) We Can Make Britain a Country That Works for Everyone. Available at: $\mathrm{http}: / / \mathrm{www} . t h e r e s a 2016 . c 0 . u k / w e$ can_make_britain_a_country_that_works_for_everyone (11 July 2016). 
Mayo, E.G. (1949) The Social Problems of an Industrial Civilization, Routledge \& Keegan Paul, London.

McCarthy, M.A. (2014) 'Turning labor into capital: pension funds and the corporate control of finance', Politics \& Society, Vol. 42, pp.455-487.

McCartin, J.A. (1998) Labor's Great War: The Struggle for Industrial Democracy and the Origins of Modern American Labor Relations, 1912-1921, University of North Carolina Press, Chapel Hill.

McGaughey, E. (2014) British Codetermination and the Churchillian Circle, UCL Labour Rights On-line Working Papers - LRI WP 2/2014.

McGaughey, E. (2015) The Codetermination Bargains: The History of German Corporate and Labour Law, LSE Law, Society and Economy Working Papers 10/2015.

Mees, B. (2015) 'Corporate governance as a reform movement', Journal of Management History, Vol. 21, pp.194-209.

Mertens, H-J. and Schanze, E. (1979) 'The German codetermination act of 1976', Journal of Comparative Corporate Law and Securities Legislation, Vol. 2, pp.75-88.

Meyers, F. (1958) 'Workers' control of industry in Europe', The Southwestern Social Science Quarterly, Vol. 39, No. 2, pp.100-111.

Miller, A.S. (1959) 'Constitutionalizing the corporation', American Behavioral Scientist, Vol. 3, pp.10-12.

Mitchell, A.D. (1998) 'Industrial democracy: reconciling theories of the firm and state', International Journal of Comparative Labour Law and Industrial Relations, Vol. 14, pp.3-40.

Mitnick, B. (1975) 'The theory of agency: the policing "paradox" and regulatory behaviour', Public Choice, Vol. 24, pp.27-42.

Müller-Jentsch, W. (2008) 'Industrial democracy: historical development and current challenges', Management Revue, Vol. 19, No. 4, pp.260-273.

Nader, R. (1984) 'Reforming corporate governance', in: Hoffmann, W.M., Mills Moore, J. and Fedo, D.A. (Eds.), Corporate Governance and Institutionalising Ethics: Proceedings of the Fifth National Conference on Business Ethics, Lexington Books, Lexington, MD.

Nader, R, Green, M.J. and Seligman, J (1976) Taming the Giant Corporation, Norton, New York.

Neuloh, O. (1956) Die deutsche Betriebsverfassung und ihr Sozialformen bis zur Mitbestimmung, Mohr, Tübingen.

Nyland, C., Bruce, K. and Burns, P. (2014) 'Taylorism, the international labour organization, and the genesis and diffusion of codetermination', Organisation Studies, Vol. 35, No. 8, pp.1149-1169.

Paranque, B. and Willmott, H. (2014) 'Cooperatives - saviours or gravediggers of capitalism? Critical performativity and the John Lewis Partnership', Organization, Vol. 21, No. 5, pp.604-625.

Patmore, G. (2016) Worker Voice: Employee Representation in the Workplace in Australia, Canada, Germany, the UK and the US 1914-1939, Liverpool University Press, Liverpool.

Peterson, R.B. (1968) 'The Swedish experience with industrial democracy', British Journal of Industrial Relations, Vol. 6, No. 2, pp.185-203.

Pinha e Cuna, M., Rego, A. and Clegg, S. (2010) 'Obedience and evil: from Milgram and Kampuchea to normal organizations', Journal of Business Ethics, Vol. 97, No. 2, pp.291-309.

Prichard, A. (2013) Justice, Order and Anarchy: The International Political Theory of PierreJoseph Proudhon, Routledge, London.

Proudhon, P-J. (1857) Manuel du spéculateur à la bourse, Garnier Fréres, Paris.

Rawls, J. (1971) A Theory of Justice, Belknap, Harvard.

Robens, A. (1972) Safety and Health at Work: Report of the Committee 1970-72, HMSO, London.

Rosenberg, H. (1998) 'A Traitor to his Class: Robert A.G. Monks and the Battle to Change Corporate America, Wiley, New York. 
Sayce, S. and Gold, M. (2011) 'Revisiting industrial democracy and pension trusteeship: the case of Canada', Economic and Industrial Democracy, Vol. 32, No. 3, pp.447-497.

Sayce, S., Westar, J. and Verma, A. (2014) 'The recruitment and selection of pension trustees: an integrative approach', Human Resource Management Journal, Vol. 24, No. 3, pp.307-322.

Schmitthoff, C.M. (1976) 'Company structure and employee participation in the EEC: the British attitude', International and Comparative Law Quarterly, Vol. 25, pp.611-620.

Schwab, S.J. and Thomas, R.S. (1998) 'Realigning corporate governance: shareholder activism by labor unions', Michigan Law Review, Vol. 96, pp.1018-1094.

Shackleton, J.R. (1998) 'Industrial relations reform in Britain since 1979', Journal of Labor Research, Vol. 19, No. 3, pp.581-605.

Silvia, S.J. (2013) Holding the Shop Together: German Industrial Relations in the Post-war Era, Cornell University Press, Ithaca.

Sobel, R. (1977) The Fallen Colossus: The Great Crash of the Penn Central, Weybright \& Talley, New York.

Stitt, J. (2006) Joint Industrial Councils in British History: Inception, Adoption, and Utilization, 1917-1939, Praeger, Westport, CT.

Sturmthal, A.F. (1964) Workers Councils: A Study of Workplace Organization on Both Sides of the Iron Curtain, Harvard University Press, Cambridge, MA.

Summers, C.W. (2000) 'From industrial democracy to union democracy', Journal of Labor Research, Vol. 21, No. 1, pp.3-14.

Trevino, L.K. (1986) 'Ethical decision making in organizations: a person-situation interactionst model', Academy of Management Review, Vol. 11, pp.607-617.

Tricker, R.I. (2009) Corporate Governance: Principles, Policies, Practices, Oxford University Press, Oxford.

Van der Zwan, N. (2014) 'Making sense of financialization', Socio-Economic Review, Vol. 12, pp.99-129.

Waddington, J. and Conchon, A. (2016) Board-Level Employee Representation in Europe: Priorities, Power and Articulation, Routledge, New York.

Webb, S. and Webb, B. (1897) Industrial Democracy, Vol. 2, Longmans, Green, London.

Webb, S. and Webb, B. (1920) The History of Trade Unionism, Longmans, Green, London.

Wedderburn of Charlton, Lord. (1984) 'The legal development of corporate responsibility: for whom will corporate managers be trustees?' in Hopt, K.J. and Teubner, G. (Eds.), Corporate Governance and Directors' Liabilities: Legal, Economic, and Sociological Analyses on Corporate Social Responsibility, De Gruyter, Berlin, pp.3-54.

Westar, J. and Verma, A. (2007) 'What makes for effective labor representation on pension boards?' Labor Studies Journal, Vol. 32, No. 4, pp.382-410.

Whittall, M., Knudsen, H. and Huijgen, F. (Eds.). (2007) Towards a European Labour Identity: European Works Councils, Routledge, London.

Wilkinson, A., Golan, P., Marchington, M. and Lewin, D. (Eds.). (2010) The Oxford Handbook of Participation in Organisations, Oxford University Press, Oxford.

Williams, R. (1961) The Long Revolution, Chatto \& Windus, London.

Williamson, A. (2016) 'The Bullock report on industrial democracy and the post-war consensus', Contemporary British History, Vol. 30, No. 1, pp.119-149.

Williamson, J., Driver, C. and Kenway, P. (Eds.). (2014) Beyond Shareholder Value: The Reasons and Choices for Corporate Governance Reform, Trades Union Congress, London.

Wrege, C.D. and Stotka, A.M. (1978) 'Cooke creates a classic: the story behind F.W. Taylor's principles of scientific management', Academy of Management Review, Vol. 73, No. 4, pp.736-749. 